\title{
PENGELOLAAN SUMBERDAYA PESISIR DAN PULAU-PULAU KECIL MELALUI PENGUATAN KEARIFAN LOKAL DAN PRANATA SOSIAL MASYARAKAT NELAYAN GILI AIR, KABUPATEN LOMBOK UTARA
}

\author{
Saptono Waspodo, Chandrika Eka Larasati*, Sadikin Amir, Sitti Hilyana, Baiq Hilda Astriana
}

Program Studi Ilmu Kelautan, Universitas Mataram

Jalan Pendidikan No. 37 Mataram, Nusa tenggara Barat, 83125 Indonesia

*Alamat korespondensi: chandrikalarasati@unram.ac.id

\begin{abstract}
Keyword: Abstrak:
Sumberdaya Keberadaan kearifan lokal dalam masyarakat merupakan hasil dari proses adaptasi pesisir, turun menurun dalam periode waktu yang sangat lama terhadap suatu lingkungan pulau pulau yang biasanya didiami ataupun lingkungan dimana sering terjadi interaksi kecil, didalamnya. Seiring berjalannya waktu, dengan masuknya era globalisasi, timbullah kearifan sebuah trend modernitas yang masuk ke suatu kawasan yang menyebabkan lokal, terjadinya degradasi kearifan lokal disuatu wilayah. Salah satunya yaitu kawasan Gili pranata Air, Kabupaten Lombok Utara yang dikenal dengan kawasan wisata pesisir dan pulausosial, gili air pulau kecil. Kegiatan pengabdian ini bertujuan untuk meningkatkan pengetahuan dan adanya penguatan kearifan lokal pada masyarakat nelayan sekitar Gili Air, serta mengedepankan nilai-nilai adat dan budaya yang menjadi daya tarik dan menjadikan nilai ekonomis bagia masyarakat nelayan. Metode pendekatan yang diterapkan dalam kegiatan ini yaitu dengan melakukan metode penyelesaian masalah. Penyelesaian masalah ini meliputi penyuluhan dan pendampingan kelompok masyarakat. Hasil menunjukkan bahwa salah satu bentuk riil dari kearifan lokal yang dimiliki oleh wilayah Pulau Lombok khususnya di Desa Gili Indah adalah awig-awig. Awig-awig adalah norma hukum adat disuatu wilayah yang mengikat bagi seluruh warga adat. Masyarakat Desa Gili Indah banyak yang belum memahami isi dari awig-awig tersebut. Hal ini disebabkan oleh terputusnya informasi dari perangkat desa ke warga sekitar terutama masyarakat kalangan muda. Peraturan Desa Gili Indah lebih memadai dan lebih komprehensif untuk dilaksanakan dan dibandingkan dengan awigawig yang hanya terbatas pada pengaturan tentang pengambilan sumberdaya pesisir dan laut saja. Perlu dilakukan sosialisasi atau penyuluhan kepada masyarakat, agar mereka lebih meningkat pemahaman dan pengetahuannya tentang Peraturan Desa tersebut. Seperti halnya awig-awig yang secara terus menerus disampaikan lewat "tutur" dari para tokoh lokal maupun masyarakat dari generasi ke generasi telah terbukti mampu diadopsi dan diterima dengan baik oleh masyarakat. Hal inilah yang
\end{abstract}


merupakan salah satu kekuatan daripada awig-awig jika dilihat dari sisi penerimaan dan adopsinya pada masyarakat karena proses penyampaiannya adalah secara kontinyu dan konsisten pada setiap kegiatan masyarakat.

Panduan Sitasi (APPA $7^{\text {th }}$ edition) :

Waspodo, S., Larasati, C. E., Amir, S., Hilyana, S., \& Astriana, B.H. (2022). Pengelolaan Sumberdaya Pesisir Dan Pulau-Pulau Kecil Melalui Penguatan Kearifan Lokal Dan Pranata Sosial Masyarakat Nelayan Gili Air, Kabupaten Lombok Utara. Jurnal Pengabdian Perikanan Indonesia, 2 (1), 1-6x. http://doi.org/ 10.29303/jppi.v2i1.499

\section{PENDAHULUAN}

Kearifan lokal merupakan tata nilai kehidupan yang terwarisi dari satu generasi ke generasi berikutnya yang berbentuk religi, budaya ataupun adat istiadat yang umumnya dalam bentuk lisan dalam suatu bentuk sistem sosial suatu masyarakat (Juniarta, 2013). Keberadaan kearifan lokal dalam masyarakat merupakan hasil dari proses adaptasi turun menurun dalam periode waktu yang sangat lama terhadap suatu lingkungan yang biasanya didiami ataupun lingkungan dimana sering terjadi interaksi didalamnya. Lokal secara spesifik menunjuk pada ruang interaksi terbatas dengan sistem nilai yang terbatas pula. Sebagai ruang interaksi yang sudah didesain sedemikian rupa yang di dalamnya melibatkan suatu pola-pola hubungan antara manusia dengan manusia atau manusia dengan lingkungan fisiknya. Di beberapa wilayah di tanah air sudah banyak kearifan lokal yang menjadi contoh dalam pengelolaan lingkungan yaitu salah satunya Panglima Laot, Awig-awig di Buleleng Bali dan keberadaannya sangat mempengaruhi kelestarian lingkungan lokal tersebut diterapkan hampir turun menurun oleh masyarakat setempat (Suhartini, 2009). Hal yang sangat kontras dengan kondisi dimana saat ini budaya asing mulai masuk dengan pesat di era globalisai modern seperti sekarang ini.

Masyarakat pesisir pulau Gili Air dengan mayoritas mata pencaharian nelayan dengan basis warganya beragama islam sangat memungkinkan adanya kearifan lokal dengan dasar agama islam yang bisa digunakan sebagai profil kearifan lokal asli dipesisir pulau Gili Air sebagai acuan dalam pengelolaan masyarakat yang pro terhadap lingkungan. Sehingga dalam kehidupan masyarakat Gili Air jalannya perekonomian, agama dengan kelestarian lingkungan bisa berjalan beriringan tanpa ada salah satu yang tersisih.

Gili Air merupakan salah satu gugusan pulau Gili Matra yang memiliki keindahan baik daratan maupun lautan. Pulau kecil ini sudah dikenal sebagai kawasan wisata bahari. Keunggulan yang dimiliki oleh kawasan ini adalah keindahan alam yang masih tergolong asri yang menjadi minat para wisatawan. Kawasan ini sudah banyak dikembangkan oleh masyarakat melalui kelompok masyarakat nelayan menjadi kawasan wisata pesisir dan pulau-pulau kecil dengan sumberdayanya yang melimpah. Namun, dengan banyaknya wisatawan yang datang ke pulau ini, menyebabkan adanya penurunan dari kekhasan dari suatu daerah, seperti adanya kearifan lokal. Adanya wisatawan yang berasal dari domestic maupun mancanegara, membuat kawasan tersebut ikut dalam trend modernisasi. Apabila kondisi ini terus dibiarkan, maka dikhawatirkan kawasan tersebut akan kehilangan kearifan lokal yang telah membudaya selama ini dan akan tergerus dengan sendirinya, sehingga kawasan tersebut tidaklah memiliki ciri khas yang bisa diperlihatkan. 


\section{METODE KEGIATAN}

Kegiatan pengabdian kepada masyarakat ini dilakukan pada bulan Juli-September 2021 di Desa Gili Indah, Kabupaten Lombok Utara yang meliputi kegiatan penyuluhan dan pengumpulan kelompok masyarakat. Adapun tahapan yang dilalui dalam kegiatan pengabdian kepada masyarakat, yaitu:

1) Survei lokasi dan perizinan

Survei lokasi meliputi kegiatan peninjauan ke lokasi pengabdian, menggali informasi tentang permasalahan yang dihadapi masyarakat menggunakan metode wawancara langsung dengan masyarakat, dan studi literatur terhadap kegiatan penelitian atau pengabdian yang pernah dilakukan sebelumnya di Gili Air, Kabupaten Lombok Utara. Sedangkan perizinan meliputi kegiatan surat-menyurat, permohonan izin kepada pihak berwenang untuk menyelenggarakan kegiatan pengabdian kepada masyarakat.

2) Penyuluhan mengenai penguatan kearifan lokal

Kegiatan penyuluhan meliputi penyampaian materi mengenai jenis-jenis kearifan lokal yang terdapat di lingkungan sekitar, sehingga masyarakat mendapatkan wawasan luas yang diharapkan dapat menggugah kesadaran mereka.

3) Evaluasi

Kegiatan evaluasi dibutuhkan untuk mengetahui seberapa efektif kegiatan pengabdian ini telah dilakukan dan memberikan dampak terhadap eningkatan kinerja dari perangkat desa yang berkaitan dengan aturan perlindungan sumberdaya pesisir dan pulau-pulau kecil di Desa Gili Indah

\section{HASIL DAN PEMBAHASAN}

Sumberdaya pesisir dan pulau pulau kecil merupakan salah satu produk kelautan yang memiliki manfaat bagi manusia dan lingkungan. Sehingga sumberdaya ini harus dikelola dengan baik secara berkelanjutan. Salah satu upaya yang bisa dilakukan adalah melalui peningkatan kapasitas masyarakat dalam pengelolaan sumberdaya tersebut. Upaya peningkatan kapasitas masyarakat yang paling mudah dan paling popular adalah melalui kegiatan penyuluhan. Seperti halnya penyuluhan pada umumnya, penyuluhan Pengelolaan Sumberdaya Pesisir dan Pulau-Pulau Kecil melalui Penguatan Kearifan Lokal dan Pranata Sosial Masyarakat, telah dilaksanakan dengan metode dialogis yang lebih banyak posi waktunya untuk diskusi dan tanya jawab antara penyuluh dan peserta penyuluhan.

Kearifan lokal adalah pandangan hidup dan ilmu pengetahuan serta berbagai strategi kehidupan yang berwujud aktivitas yang dilakukan oleh masyarakat lokal dalam menjawab berbagai masalah dalam pemenuhan kebutuhan mereka dimana kearifan lokal pada dasarnya dapat dipandang sebagai landasan bagi pembentukan jati diri bangsa secara nasional yang merupakan bagian dari etika dan moralitas dalam membantu manusia untuk menjawab pertanyaan moral apa yang harus dilakukan, bagaimana harus bertindak khususnya dalam bidang pengelolaan lingkungan dan sumberdaya alam.

Salah satu bentuk riil dari kearifan lokal yang ada di wilayah Pulau Lombok dan Bali disebut awig-awig. Awig-awig adalah norma hukum adat disuatu wilayah yang mengikat bagi seluruh warga adat. Sebagai contoh, Di Teluk Sunut, Lombok masyarakat membentuk awig-awig untuk pengelolaan teripang, seperti pola bagi hasil serta zonasi penangkapan dan budidaya. Batas administerasi desa- 
desa tersebut dijadikan batas sosial untuk mengelola kawasan dengan aturan awig-awig. Peran awigawig bagi masyarakat pesisir akan nampak dalam proses pembentukan awig-awig yang banyak mengadopsi aturan-aturan lokal sehingga dalam pelaksanaanya mempunyai variable pokok yang hampir sama dengan hak ulayat laut, yaitu wilayah, unit sosial pemegang hak dan legalitas beserta pelaksanaanya. Bahkan lebih daripada itu terbentuknya awig-awig diilhami oleh kegiatan upacara adat menyawen sehingga dalam pembentukannya hingga pelaksanaannya masih dipengaruhi oleh unsurunsur sosial budaya masyarakat setempat. Dalam pelaksanaannya, kegiatan penangkapan ikan diwilayah awig-awig bersifat individual bagi masyarakat dalam, artinya bahwa setiap orang berhak untuk melakukan kegiatan penagkapan asalkan alat-alat yang digunakan sesuai dengan aturan yang telah ditetapkan pada zona awig-awig. Sementara untuk nelayan dari luar yang melakukan penangkapan harus mendapat izin dari Dinas Perikanan dan Kelautan setempat.

Pelaksanaan awig-awig harus dilakukan secara tegas oleh Lembaga Musyawarah Nelayan Lombok Utara dengan beberapa jenis sanksi yaitu: - sanksi berupa denda; - Sanksi berupa pembakaran alat tangkap; - Sanksi pemukulan massa namun tidak sampai mati. Hal inilah yang menjadi salah satu kelemahan daripada awigawig yang dianggap kurang manusiawi oleh karena itu banyak warga masyarakat kemudian menginginkan dilakukan perubahan. Selain daipada itu karena awig-awig juga sangat spesifik terhadap substansi yang diatur, sementara disisi lainnya karena perkembangan kondisi dan kebutuhan masyarakat yang ingin ditertibkan maka awig-awig sudah kurang cocok lagi untuk digunakan. Oleh karenanya dibenyak tempat awig-awig dirubah menjadi Peraturan Desa (PERDES).

Sejak ditetapkannya Peraturan Desa Gili Indah Nomor 4 tahun 2014 tentang Kemasyarakatan yakni pada tanggal 29 Oktober 2014; maka Desa Gili Indah secara resmi tidak menggunakan lagi awigawig dalam pengelolaan lingkungan, karena semua awig-awig yang berkaitan dengan hal tersebut telah dirumuskan dalam peraturan desa. Oleh karena itu, tim penyuluh melakukan kegiatan berlandaskan pada Peraturan Desa tersebut.

Penyuluhan pengelolaan sumberdaya pesisir dan pulau-pulau kecil yang disebabkan karena telah memiliki pemahaman dan ilmu yang memadai unuk mengelola sumberdaya tersebut. Target luaran dari kegiatan ini adalah peningkatan kesadaran dan pengetahuan masyarakat terkait penerapan serta pelaksanaan daripada awig-awig masyarakat yang merupakan kearifan lokal dan saat ini telah di formalkan menjadi sebuah Peratuaran Desa (PERDES) Desa Gili Indah Nomor 04 Tahun 2014, tentang Kemasyarakatan.

Untuk menjaga agar tidak terjadi pelanggaran dan memberikan efek jera bagi masyarakat maka diperlukan adanya sanksi dalam pelaksanaannya. Namun demikian sanksi yang diberikan juga harus mempertimbangkan sisi kemanusiaan dan tidak berakibat fatal. Berikut adalah beberapa sanksi yang diberlakukan yakni :

1. Apabila melanggar ketentuan pasal 18 ayat $1 \mathrm{~s} / \mathrm{d} \mathrm{5}$, maka akan dikenakan denda berupa membeli bak sampah;

2. Apabila melanggar ketentuan pasal 18 ayat 6 , maka kusir yang menjatuhkan kotoran kuda dan tidak membersihkan dikenakan sanksi berupa sekors tidak boleh menambang selama dua hari dan dikenakan denda sebesar Rp. 250.000,- . Dan apabila kusir yang melihatnya dan tidak membersihkan maka dikenakan sekors tidak boleh menambang satu hari;

3. Apabila melanggar ketentuan pasal 18 ayat 9 , maka akan dikenakan denda sebesar Rp. 100.000,; 
4. Apabila melanggar ketentuan pasal 18 ayat 10 , maka tidak perbolehkan untuk melakukan kegiatan proyek.

Sebagai bentuk tanggungjawab pihak desa sebagai pengelola pemberlakuan Perdes Desa Gili Indah dan untuk melakukan transparan serta meningkatkan kepercayaan masyarakat, maka pada bagian akhir dari perdes, yakni pada pasal 28 ditegaskan bahwa : Semua denda yang diperoleh tersebut dimasukkan ke Anggaran Pendapatan dan Belanja Desa Gili Indah.

Dengan mempertimbangkan kelengkapan serta jangkauan daripada substansi peraturan maka dalam hal ini dapat disimpulkan bahwa Peraturan Desa Gili Indah lebih memadai dan lebih komprehensif untuk dilaksanakan dan dibandingkan dengan awig-awig yang hanya terbatas pada pengaturan tentang pengambilan sumberdaya pesisir dan laut saja. Namun demikian mengingat sebagian besar masyarakat Desa Gili Indah kurang gemar membaca terlebih lagi harus membaca Peraturan Desa, maka langkah yang paling baik adalah perlu lebih sering dilakukan sosialisasi atau penyuluhan kepada masyarakat, agar mereka lebih meningkat pemehaman dan pengetahuannya tentang Peraturan Desa tersebut. Seperti halnya awig-awig yang secara terus menerus disampaikan lewat "tutur" dari para tokoh lokal maupun masyarakat dari generasi ke generasi telah terbukti mampu diadopsi dan diterima dengan baik oleh masyarakat. Hal inilah yang merupakan salah satu kekuatan daripada awig-awig jika dilihat dari sisi penerimaan dan adopsinya pada masyarakat karena proses penyampaiannya adalah secara kontinyu dan konsisten pada setiap kegiatan masyarakat. Sedangkan sisi kelemahan dari pada Peraturan Desa adalah tidak dilakukan secara kontonyu dan konsisten serta ada kecenderungan peyampaiannya secara formal.

\section{KESIMPULAN DAN SARAN}

Kegiatan pengabdian kepada masyarakat berupa penyuluhan mengenai pengelolaan sumberdaya pesisir dan pulau-pulau kecil melalui kearifan lokal dan pranata sosial di Desa Gili Indah, Kabupaten Lombok Utara, masyarakat setempat telah mendapatkan informasi dan pemahaman terkait isi dari aturan awig-awig tersebut. Sehingga tidak hanya kalangan tua saja yang mengetahui aturan tersebut, namun kalangan mudapun mengetahuinya.

Kegiatan ini dapat dijadikan sebagai penambah frekuensi kegiatan sosialisasi dari Peraturan Desa yang telah dibuat namun minim sosialisasi karena kurangnya sumberdaya yang tersedia di tingkat desa. Oleh karena itu, masyarakat dan aparat desa sangat berharap untuk dapat dilakukan kegiatan pengabdian dalam bentuk apapun dengan materi yang lainnya pada waktu mendatang.

\section{UCAPAN TERIMA KASIH}

Penulis mengucapkan terima kasih kepada masyarakat Desa Gili Indah yang ikut berpartisipasi dalam kegiatan penyuluhan dalam rangka meningkatkan pengetahuannya terkait aturan desa dalam mengelola sumberdaya pesisir dan pulau-pulau kecil. Selain itu, terima kasih juga kepada mahasiswa program studi IImu Kelautan Universitas Mataram yang ikut terlibat dan membantu dalam pelaksanaan kegiatan ini. 


\section{DAFTAR PUSTAKA}

Juniarta HG, Susilo E, Primyastanto M. 2013. Kajian Profil Kearifan Lokal Masyarakat Pesisir Pulau Gili Kecamatan Sumberasih Kabupaten Probolinggo Jawa Timur. Jurnal ECSOFiM, vol 1 (1): 11 25.

Ridwan, Nurma A. 2007. Landasan Keilmuan Kearifan Lokal. Jurnal STAIN Purwokerto. Purwokerto.

Sulaiman. 2010. Model Alternatif Pengelolaan Perikanan Berbasis Hukum Adat Lhaot di Kabupaten Aceh Jaya Menuju Keberlanjutan Lingkungnaan yang Berorientasi Kesejahteraan Masyarakat. Universitas Diponegoro. Semarang.

Suhartini. 2009. Kajian Kearifan Lokal Masyarakat dalam Pengelolaan Sumberdaya Alam dan Lingkungan. Jurnal Uniersitas Negeri Yogyakarta. Yogyakarta. 